\title{
Physicochemical Properties and Antioxidant Activity of Mixed Oil of Safou (Dacryodes edulis (G. Don) H.J. Lam) from Several Trees
}

\author{
Alain Serges Ondo-Azi ${ }^{1,2}$, Crépin Ella Missang ${ }^{1} \&$ Thomas Silou ${ }^{3}$ \\ ${ }^{1}$ Laboratoire Sciences des Aliments, Université des Sciences et Techniques de MASUKU, Franceville, Gabon \\ ${ }^{2}$ Pôle Régional de Recherche Appliquée au développement des Systèmes Agricoles d'Afrique Centrale \\ (PRASAC), N'Djamena, Tchad \\ ${ }^{3}$ Ecole Doctorale T2A, Faculté des Sciences et Techniques Université Marien NGOUABI, Brazzaville, Congo \\ Correspondence: Alain Serges Ondo-Azi, Université des Sciences et Techniques de MASUKU, BP 901 \\ Franceville, Gabon. E-mail: ondoazi@yahoo.fr
}

Received: April 9, 2020

doi:10.5539/jfr.v9n4p50
Accepted: June 19, $2020 \quad$ Online Published: July 7, 2020

URL: https://doi.org/10.5539/jfr.v9n4p50

\begin{abstract}
The valorization of lipids can be highlighted by industrial exploitation of safou pulp, very rich in these. However, the low yield of safou trees is lacking. It's necessary to estimate the technological potentialities of the oil obtained in order to describe the nutritional value and potential exploitation of this oil. Physical and chemical characteristics of this oil were examined. The aim of our study was to extract oil from fruits of several safou fruits and prepared a unique sample. This sample was essayed for its physicochemical properties and antioxidant activity. Results showed that the refractive index was 1.4693 . The density and viscosity values were $0.9 \mathrm{mg} / \mathrm{mL}$ and $31.08 \mathrm{mPa} / \mathrm{s}$, respectively. Acid and peroxide values were $6.17 \mathrm{mg} \mathrm{KOH} / \mathrm{g}$ and $31.46 \mathrm{meq} \mathrm{O}_{2} / \mathrm{kg}$. Gas chromatography revealed that the major fatty acids were C16:0 (44.23\%), C18:1 (30.50\%), and C18:2 (19.62\%). Triacylglycerols were the most important lipids ( $88.88 \%$ of total lipids). Spectrometric assessment of color led to the remarkable presence of the peaks associated with the visible absorption of carotenoids near $530 \mathrm{~nm}$ and chlorophyll pigments located between 610 and $670 \mathrm{~nm}$. Antioxidant activity and DPPH radical scavenging activities of safou oil were exanimate. So, oil mixtures can be used, while varietal delimitation and mix some varieties for oil industry.
\end{abstract}

Keywords: mixing, safou, oil characteristics, antioxidant potential

\section{Introduction}

The safou tree, Dacryodes edulis (G.Don) H.J. Lam (Burseraceae family) is an important native resource of the Gulf of Guinea. It is a multifunctional plant and valued for its medicinal, nutritional, economic, and social uses. D. edulis is an important food commodity which has had enormous attention in central Africa (Mollet et al., 1995; Ajebesin, 2011). The pulp, the only edible part of the fruit, is particularly rich in lipids (50-70\% of dry matter), indicating that safou could be an important source of oil. Proteins and sugars account for $10 \%$ and $30 \%$ of dry matter, respectively. The pulp contains minerals (3\% of dry matter), and vitamins (Silou, 2012; Kadji et al., 2016). Kapseu et al. (1998) reported that one safou tree is able to produce about $40-50 \mathrm{Kg}$ of oil, corresponding to 4-5 t/ha. The oil obtained of pulp presents a nutritional interest with an important proportion of linoleic (17 $24 \%)$ and oleic $(28-32 \%)$ acids. This oil can be used for food, pharmaceutical cosmetic industries (Ajibesin, 2011; Grigoras, 2012; Enengedi et al., 2019). Studies reveal that safou fruit can be used as an alternative source of fats and oil (Silou, 2012; Okpala, 2015; Akusu \& Wordu, 2019).

However, the absence of varietal delimitation of this specie limits the optimal exploitation of safou oil. In fact, the specific taxa existing in Dacryodes edulis are not clearly differentiated and delimited.

The objective of the present study was therefore to extract oil from fruits collected from several safou trees in Franceville, assess the physical and chemical characteristics, and propose possible uses for this oil mixture as preliminary investigations into the scientific basis for its use for edible purposes. 


\section{Material and Methods}

\subsection{Study Area}

This study was conducted from March 2019 in Franceville city (1 $\left.{ }^{\circ} 37^{\prime} \mathrm{S}, 13^{\circ} 35^{\prime} \mathrm{E}\right)$ in Gabon.

\subsection{Material}

Mature fruits were picked on 200 trees randomly selected in home gardens in Franceville city (Gabon). Samples of 20 fruits were manually collected for each tree and transported to the laboratory for oil extraction.

\subsection{Methods}

\subsubsection{Oil Extraction}

The extraction of lipids was made by the Soxhlet method by using multi-unit apparatus (model Soxtec System HT 1043). Five grams of dried and crushed safou pulp was placed in a cartridge of the Soxhlet apparatus for 200 samples. After a 1 hour extraction with hexane as solvent, the solvent was evaporated under reduced pressure and solvent traces eliminated by oven drying after extraction.

Apparatus characteristics:

- Maximum volume of sample: $65 \mathrm{ml}$ (oil extraction cartridge measurements: 33 X $88 \mathrm{~mm}$ ).

- Capacity: 6 samples.

- Temperature: from 20 to $285^{\circ}$ during 10 minutes.

\subsubsection{Sample Preparation}

After oil extraction, a sample of $2 \mathrm{~mL}$ of safou oil was taken in each of 200 samples obtained. The mixture was prepared by successive returning. The mixing oil obtained was considered as the unique sample used from several analysis.

\subsubsection{Oil Characteristics}

Physical and chemical analysis (relative density, refractive index, viscosity, acid value, iodine index, saponification index, peroxide value, and unsaponifiable matter) of oil samples were carried out by using standard methods described by French Association for Standardization (AFNOR, 2000).

\section{Relative density (or specific gravity)}

Relative density is defined as mass per unit volume of a fluid. Oil density was determined picnometrically. The relative density of the oil was determined gravimetrically by employing the weight ratio of the oil to the equivalent amount of water according to the following formula:

$$
\text { Relative density }=\frac{W 2}{W 1}
$$

Where, W2 and W1 are the weights of oil and the equivalent amount of water, respectively.

\section{Refractive index}

The refractive value of oil was measured using a precision Abbe refractometer, having a measuring range of refractive index of $1,300-1,700$ with the accuracy \pm 0.0002 at $25^{\circ} \mathrm{C}$.

\section{Viscosity}

The viscosity of oil is a measure of its resistance to internal flow and an indication of its oiliness in the lubrication of surfaces. The kinematic viscosity of mixing safou oil was measured using Ostwald U-tube viscometer. The measurements were held in a controlled temperature bath at $25^{\circ} \mathrm{C}$. The reference liquid was water where its viscosity $\left(\eta_{r}\right)$ at $25^{\circ}$ is $1.002 \mathrm{cP}$. The viscosity $(\eta)$ of safou oil was calculated using formula:

$$
\operatorname{Viscosity}(\eta)=\frac{W \cdot T \cdot \eta r}{W r \cdot T r}
$$

Where $\mathrm{W}$ and $\mathrm{T}$ is the mass and time flow of the safou mixing oil and $\mathrm{Wr}$ and $\mathrm{Tr}$ is the mass and time flow of the water, respectively.

\section{Spectrometric Evaluation of color}

Place in a $10 \mathrm{~mL}$ volumetric flask, $1 \mathrm{~g}$ of fat previously melted at $40^{\circ} \mathrm{C}$, complete to volume with carbon tetrachloride $\left(\mathrm{CCl}_{4}\right)$, the resulting solution was filtered. It measures the absorption between 400 and $700 \mathrm{~nm}$ at the maxima of the absorption of the main pigments of vegetable oils: carotenoids, chlorophyll (Helmy, 1990), 
using a spectrophotometer (Model GENESIS 10).

Acid value

Ethanol was boiled on a water bath for a few minutes to remove dissolved gases. The boiled ethanol was neutralized by adding a few drops of phenolphthalein and about $10 \mathrm{ml} 0.1 \mathrm{~N}$ potassium hydroxide until a pale pink color was obtained. 2-3 g of oil was weighed into a $250 \mathrm{~mL}$ conical flask and $50 \mathrm{ml}$ of hot previously neutralized ethanol was added. The mixture was then brought to a boil on a water bath and the hot mixture was titrated with $0.1 \mathrm{~N}$ potassium hydroxide solution until the pink color (stable for few minutes) returned. The acid value was calculated from the relation shown in the equation:

$$
\text { Acid value }(\mathrm{mgKOH} / \mathrm{g})=\frac{V \cdot N \cdot 56.1}{W}
$$

Where, $\mathrm{V}$ is titer value $(\mathrm{mL}), \mathrm{N}$ is normality of $\mathrm{KOH}=0.1 \mathrm{~N}$ and $56.1=$ molar mass of $\mathrm{KOH}$ and $\mathrm{W}$ is the weight of sample.

\section{Free fatty acid (FFA)}

The percentage free fatty acid (as palmitic acid) was obtained by multiplying the acid value with the factor 0.503 (Akubugwo et al., 2008). Thus, percentage FFA (as oleic acid) $=0.503 \mathrm{X}$ acid value.

\section{Saponification value}

About $2 \mathrm{~g}$ of oil was weighed into a conical flask and mixed with $25 \mathrm{ml}$ of $0.5 \mathrm{~N}$ ethanolic $\mathrm{KOH}$. A blank was also prepared by taking $25 \mathrm{~mL}$ of alcoholic $\mathrm{KOH}$ in a similar flask. Reflux condensers were fitted to both flasks and the contents were heated in a water bath for one hour, swirling the flask from time to time. The flasks were then allowed to cool a little and the condensers washed down with a little distilled water. The excess $\mathrm{KOH}$ was titrated with $0.5 \mathrm{~N} \mathrm{HCl}$ acid using phenolphthalein as an indicator. The saponification value was calculated using the equation:

$$
\text { Saponification value }(\mathrm{mgKOH} / \mathrm{g})=\frac{(a-b) \cdot F \cdot 56.1}{W}
$$

Where, $\mathrm{b}=$ titer value of blank $(\mathrm{mL}), \mathrm{a}=$ titer value of sample $(\mathrm{mL}), \mathrm{F}=$ factor of $0.5 \mathrm{~N} \mathrm{HCl}=1$ (in this case) and $28.05=\mathrm{mg}$ of $\mathrm{KOH}$ equivalent to $1 \mathrm{ml}$ of $0.5 \mathrm{~N} \mathrm{HCl}$ and $\mathrm{W}$ is weight of sample.

\section{Peroxide value}

Two grams of oil sample was weighed into a $500 \mathrm{~mL}$ conical flask and $10 \mathrm{~mL}$ of chloroform was added to dissolve the sample. This was followed by the addition of $15 \mathrm{ml}$ of acetic acid and $1 \mathrm{ml}$ of freshly prepared saturated potassium iodide solution. The flask was immediately closed, stirred for about 1 minute, and kept at room temperature away from light for exactly 5 minutes. About $75 \mathrm{~mL}$ of distilled water and $3 \mathrm{ml}$ of starch poison were added to the content of the flask and then shaken vigorously. Few drops of starch solution were added as an indicator. The liberated iodine was titrated against $0.01 \mathrm{~N}$ sodium thiosulphate solution. The same procedure was carried out for blank and the peroxide value expressed in milliequivalent of active oxygen per kilogram of sample was calculated using

$$
\text { Peroxide value }\left(\mathrm{mgO}_{2} / \mathrm{Kg}\right)=\frac{(V 1-V 0) \cdot T \cdot 1000}{W}
$$

Where, V0 is the volume of the sodium thiosulphate solution used for blank, V1 is the volume of the sodium thiosulphate solution used for determination of sample, $\mathrm{T}$ is the normality of the sodium thiosulphate used, and $\mathrm{W}$ is the mass of the test sample in grams.

\section{Iodine value}

Approximately $0.2 \mathrm{~g}$ of oil sample was weighed into a dry $250 \mathrm{~mL}$ glass stopper bottle and $15 \mathrm{ml}$ of chloroform was added to the oil. About $25 \mathrm{~mL}$ of Wij's solution was then added and allowed to stand in the dark for 1 hour. Twenty $\mathrm{mL}$ of $10 \%$ Potassium Iodide $150 \mathrm{~mL}$ of water and $2 \mathrm{~mL}$ of starch poison at $0.5 \%$ were added and the resulting mixture was then titrated with $0.1 \mathrm{~N}$ Sodium thiosulphate solution using starch as indicator just before the endpoint. A blank determination was carried out alongside the oil samples.

Iodine value was calculated thus:

$$
\text { Iodine value }=\frac{(V 2-V 1) \cdot N \cdot 12.69}{W}
$$


Where, $\mathrm{V} 2=$ titer value for blank, V1 = titer value for sample and $1.269=$ Concentration conversion coefficient and $\mathrm{W}$ is weight of sample (g).

\section{Unsaponifiable matter content}

Unsaponifiable matter content of oil was determined following international chemical methods. The oil sample $(5 \mathrm{~g})$ was saponified with $50 \mathrm{~mL}$ of $2 \mathrm{~N} \mathrm{KOH}$ methanolic solution for 1 hour. To the resulted mixture, $50 \mathrm{~mL}$ of distilled water was added. The unsaponifiable matter was extracted three times with $50 \mathrm{~mL}$ of hexane-ether (60:40). Organic fractions were collected, washed three times with $50 \mathrm{~mL}$ of distilled water, and then dried with sodium sulfate. Hexane-ether was removed in a rotary evaporator to recover the unsaponifiable matter which was then weighed.

\section{Determination of fatty acids composition}

Fatty acid composition of safou oil was determined using gas chromatography using a flame ionization detector (GC-FID) as fatty methyl ester (FAME) according to Rohman and Che man (2009) with slight modification. FAMEs were prepared by adding $1 \mathrm{~mL}$ of $\mathrm{n}$-hexane and $400 \mu \mathrm{L}$ of $1 \mathrm{M}$ sodium methoxide to $60 \mu \mathrm{L}$ of safou oil. The tube was stoppered, and the contents vigorously mixed with a dry water bath for 30 seconds. After this, 400 $\mu \mathrm{L}$ of $1 \mathrm{~N}$ hydrochloric acid and $1 \mathrm{~mL}$ cyclohexane were added. The organic phases were analyzed by gas chromatography on a Hewlett-Packard apparatus (HP 5890 series) fitted with a polar capillary column (Ref. HP FFAP No. 559436116, $25 \mathrm{~m} \mathrm{x} 0.20 \mathrm{~mm}$ internal diameter, CA, USA) and a flame ionization detector (FID).

Analyses were carried out at a constant temperature of $235^{\circ} \mathrm{C}$; injector and detector were set at $250^{\circ} \mathrm{C}$; helium was used as carrier gas ( $160 \mathrm{kPa}, 2 \mathrm{~mL} / \mathrm{min})$. FAMEs were identified by comparison of their retention times with those of authentic standards (Sigma Aldrich Co, St Louis, Mo., USA), and quantification was performed by internal standardization.

\section{Determination of lipid classes}

Free fatty acid (FFA), mono- (MAG), di- (DAG), and triacylglycerol (TAG) were determined by gas chromatography. Crude oil $(1 \mathrm{~g})$ was dissolved in $15 \mathrm{~mL}$ of chloroform. The extract underwent preparative column chromatography on silica gel (Merck 0.10-0.15 mm, Darmstadt, Germany). This gave three fractions: the TAG fraction was eluted with benzene, the DAG, and FFA fraction with a mixture of diethyl ether/benzene: 10: 90 (v: v) and the MAG fraction with diethyl ether. The purity of the three fractions was checked by thin-layer chromatography (TCL), using silica gel ascending development with hexane/diethyl ether 80: 20 (v: v) and visualization with chromic-sulphuric acid at $180^{\circ} \mathrm{C}$. Each fraction was analyzed by gas chromatography with a FISON GC 8000 gas chromatograph equipped with an FID detector. The capillary column was $15 \mathrm{~m}$ CP Sil 8CB fused silica capillary ( $15 \mathrm{~m} \mathrm{x} 0.25 \mathrm{~mm}$ internal diameter, $0.25 \mu \mathrm{m}$ film thickness, Canada). Programmed oven temperature was used, starting at $80^{\circ} \mathrm{C}$ and then ramped to $360^{\circ} \mathrm{C}$ at $10^{\circ} \mathrm{C} / \mathrm{min}$; the detector temperature was $365^{\circ} \mathrm{C}$. The carrier gas was helium. Samples $(1 \mu \mathrm{L})$ were injected using an on-column injector. Peaks were recorded and identified against authentic standards by comparison of retention times. Peak areas were computed using internal normalization.

\section{Antioxidant Activity Determination}

The antioxidant activity of the safou oil sample was measured by the 1,1-diphenyl-2-picrylhydrazyl (DPPH) radical scavenging assay (Hatano et al, 1988; Bhatnagar et al., 2009). $2.5 \mathrm{~mL}$ of oil solution of various concentrations $(0,0.3875,0.75,1.5$, and $3 \mathrm{mg} / \mathrm{mL})$ prepared in methanol was added into $1.0 \mathrm{~mL}$ of methanolic solution of DPPH $(0.3 \mathrm{mM})$ and kept in the dark at room temperature for 30 minutes. The freshly prepared solutions of DPPH at a concentration of $10^{-4} \mathrm{M}(4 \mathrm{~mL})$ were added to the sample $(50 \pm 1 \mathrm{mg})$. This mixture was vortexed for $20 \mathrm{~s}$ and absorbance was measured at $517 \mathrm{~nm}$ in the UV-Visible spectrophotometer (Model GENESIS 10) and then kept at room temperature. After incubation for $30 \mathrm{~min}$, the decreases in absorbance at $517 \mathrm{~nm}$ were monitored for this sample. The radical scavenging activity (RSA) was estimated from the difference in the absorbance of the methanolic DPPH solution with and without oil (control). The percent inhibition was calculated from the following equation:

$$
\operatorname{RSA}(\%)=\left(\frac{A 0-A}{A 0}\right) \times 100
$$

Where $\mathrm{A} 0$ is the absorbance of the control and $\mathrm{A}$ is the absorbance of the samples.

Three replicates for each sample were assay.

The $\mathrm{IC}_{50}$ value representing the concentration of the compounds that cause $50 \%$ inhibition of radical formation 
was obtained by interpolation from linear regression analysis (Stoilova et al., 2007).

The antiradical power (ARP) of extracts calculated as (Suja et al., 2005):

$$
\mathrm{ARP}=\frac{1}{E C 50}
$$

Antioxidant activity index (AAI) was calculated as follows:

$$
\mathrm{AAI}=\frac{\text { Final concentration of } D P P H(\mu \mathrm{g} \cdot \mathrm{mL}-1)}{I C 50(\mu \mathrm{g} \cdot \mathrm{mL}-1)}
$$

where the final concentration of the reaction was $49.79 \mu \mathrm{g} \cdot \mathrm{mL}^{-1}$.

\subsubsection{Statistical Analysis}

For physicochemical parameters (without spectrum, fatty acid composition, lipid classes and antioxidant activity), values represented are the mean and standard deviations for three replicates. Statistical analysis was carried out by Excel version 8.0 software.

\section{Results and Discussion}

\subsection{Physicochemical Characteristics}

The physicochemical characteristics of mixing oil are presented in Table 1.

Table 1. Physicochemical characteristics

\begin{tabular}{lc} 
Physicochemical properties & \\
\cline { 2 - 2 } Parameters & Values (SD) \\
\cline { 2 - 2 } Relative density $\left(20^{\circ} \mathrm{C}\right)$ & $0.91(0.006)$ \\
Refractive index $\left(20^{\circ} \mathrm{C}\right)$ & $1.4693(0.001)$ \\
Viscosity $(\mathrm{mPa} . \mathrm{s})$ & $31.08(2.71)$ \\
Acid value $(\mathrm{mg} \mathrm{KOH} / \mathrm{g})$ & $6.17(0.407)$ \\
Free fatty acid $(\%)$ & $3.10(0.407)$ \\
Peroxyde value $\left(\mathrm{meq} \mathrm{O}_{2} / \mathrm{kg}\right)$ & $31.46(3.76)$ \\
Saponifiable value $(\mathrm{mg} \mathrm{KOH} / \mathrm{g})$ & $201.49(8.08)$ \\
Iodine value $(\mathrm{mgI} / 100 \mathrm{~g})$ & $68.48(2.66)$ \\
Unsaponifiable matter $(\%)$ & $0.72(0.07)$ \\
\hline
\end{tabular}

SD: standard deviation

\subsubsection{Physical Parameters}

The physical properties that were studied are following: relative density, refractive index, kinematic viscosity, and spectrum in visible. The value of relative density was $0.91 \pm 0.06$ while the refractive index was about $1.4693 \pm 0.00$. The specific gravity and refractive index of $D$. edulis oil are within the range of those reported for most conventional edible oils (Nzikou et al., 2011; Codex Alimentarius, 2015); and higher than that of palm (Karleskind \& Wolf, 1992; Codex Alimentarius, 2015).

Viscosity describes a fluid's internal resistance to flow and may be thought of as a measure of fluid friction. Viscosity value obtained was $31.08 \mathrm{mPa}$.s. This value is near to palm oil (34-36) viscosity and lower inside sunflower (40-44) oil (Blin et al., 2013).

\section{Spectrometric Evaluation of color}

The measurement of absorption between 400 and $700 \mathrm{~nm}$ provides information on the intensity of the color of the oil studied. The figure 1 represents the absorption spectrum in this area of the visible of oil sample of Dacryodes edulis.

The spectrum showed two (2) maximum absorbance

The visible domain of this spectrum showed two (2) maximum absorbances (1.68 and 0.96) at 420 and $660 \mathrm{~nm}$, respectively.

As shown in this figure 1, the spectrum exhibits the light absorption maxima of carotenoids around $430 \mathrm{~nm}$ and $490 \mathrm{~nm}$, and two very distinctive absorption maximum corresponding to the chlorophyll pigments between 610 and $670 \mathrm{~nm}$. Mampouya (2006) also identified this double peak in the same areas in safou pulp oil from Congo. 
These results corroborate those of Helmy (1990) who studying the oils extracted from seeds of citrus and cucurbits, identified absorption maxima at 400, 425, 455, $480 \mathrm{~nm}$ for carotenoids, at $610,670 \mathrm{~nm}$ for chlorophylls.

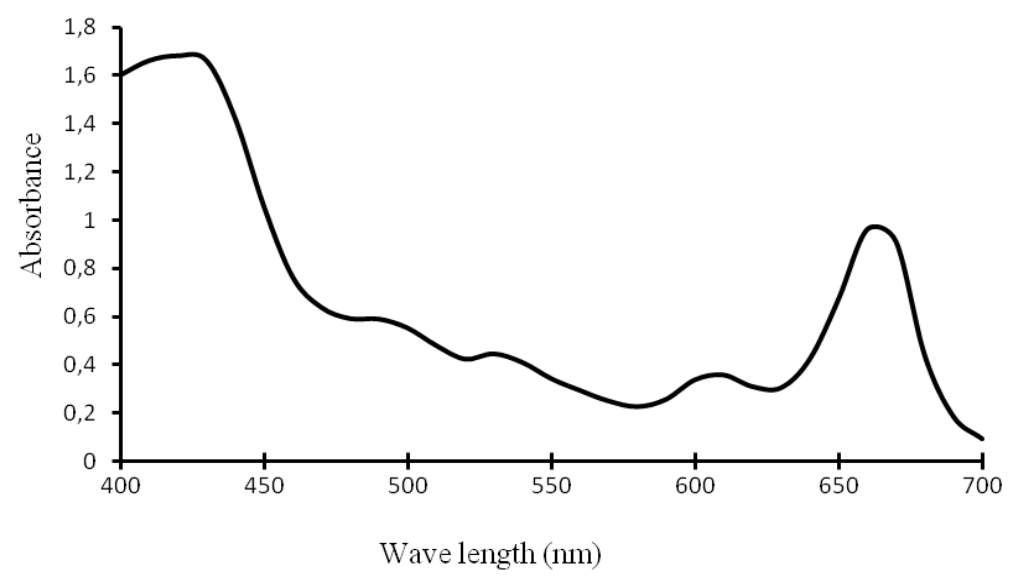

Figure 1. Spectrum in visible of safou oil

The absorption spectrum of our oil sample has another peak around $530 \mathrm{~nm}$. This peak may well correspond to the unknown pigment than Helmy (1990) located at 525, $570,575 \mathrm{~nm}$. All this allows us to conclude that the fat of Dacryodes edulis contains carotenoids and chlorophylls which are majority and confirm the slightly greenish coloration observed to the naked eye.

\subsubsection{Chemical Parameters}

The chemical parameters that were studied are following: acid value, free fatty acid, peroxide value, saponification value, iodine value and unsaponifiable matter.

Acidity, which corresponds to free fatty acids (FFA) level, was around $6.17 \mathrm{mg} \mathrm{KOH} / \mathrm{g}$, slightly higher than the limit value of $4 \%$ indicated by Codex Alimentarius (2015) for crude oil. This high value probably results from increasing of oxidative degradation of oil during the long sample storage time before its extraction (more than 1 year) (Noumi et al., 2014). In the same way, the high peroxide value recorded $\left(31.46 \mathrm{meqO} \mathrm{O}_{2} / \mathrm{kg}\right.$ ) was certainly due to oil alteration during storage as previously suggested by Foukou et al. (2009) for other crude oils extracted from African non-conventional oil crops. Codex Alimentarius (2015) proposes $10 \mathrm{meqO} \mathrm{O}_{2} / \mathrm{kg}$ for oil. The saponification value was relatively high $(201.49 \mathrm{mg} \mathrm{KOH} / \mathrm{g})$ suggesting that this oil is suitable for soap making and the manufacture of lather shaving creams. The high saponification values recorded for the seed oils suggest that the oils contain high molecular weight fatty acids and low levels of impurities. This is evidence that the oil could be used in the soap making industry (Enengedi et al., 2019). Iodine value was $68.5 \mathrm{mgI} / 100 \mathrm{~g}$ oil, close to other results obtained on D. edulis (Akusu \& Wordu, 2019; Enengdi et al., 2019). These authors show that Iodine value range at 50.25 - 58.05. Unsaponifiable matter content was rather low $(0.72 \%)$ compared to results previously published by Loemba-Ndembi \& Silou (2006) and Ondo-Azi et al. (2014) on safou pulp oil.

\subsection{Fatty Acid Composition}

Fatty acids (FAs) are part of the lipid class. They are saturated or unsaturated (Nagy \& Tiuca, 2017). The major saturated fatty acid in D. edulis pulp oil was palmitic acid (44.23\%); the main unsaturated fatty acids were oleic acid $(30.50 \%)$ and linoleic acid $(19.62 \%)$ with small amounts of stearic $(2.88 \%)$ and linolenic $(0.78 \%)$ (Table 2). The fatty acids order $(\% \mathrm{P}>\% \mathrm{O}>\% \mathrm{~L}>\% \mathrm{~S}>\% \mathrm{Ln})$ corresponds to the profile described by several authors on safou oils (Silou et al., 2002; Ondo-Azi et al., 2014). In opposite to the other authors, Akusu \& Wordu (2019) reported another fatty acid order never described in safou oil: $\% \mathrm{O}>\% \mathrm{~L}>\% \mathrm{P}>\% \mathrm{~S}$, obtained on one sample from Nigeria. It's different from four profiles described on fatty acids from safou oil from Gabon among 213 safou trees respectively (Ondo-Azi et al., 2014).

However, oil of safou pulp is therefore an important source of unsaturated fatty acids. That is an important information because polyunsaturated fatty acid-rich diet contributes to the beneficial effects on human health (Fomuso \& Akoh, 2002) and should help the general population to live longer (Carvalho \& Caramujo, 2018). 
Table 2. Fatty acid composition of mixing safou oil

\begin{tabular}{llll}
\hline \multicolumn{3}{l}{ Fatty acid compositions } & \\
\hline Fatty acids & Percentage & Fatty acids & Percentage \\
\hline C14:0 & 0.11 & C18:0 & 2.88 \\
C14:1 & 0.03 & C18:1 & 30.5 \\
C15:0 & 0.24 & C18:2 & 19.62 \\
C16:0 & 44.23 & C18:3 & 0.78 \\
C16:1 & 0.18 & C20:0 & 0.14 \\
C17:0 & 0.15 & C20:1 & 0.07 \\
\hline
\end{tabular}

Safou oil contains linoleic acid (30.5), which is an essential polyunsaturated fatty acid. This type of fatty acid helps in the prevention of vascular heart diseases and are supplied only in food. Besides, the oil of safou has a greater amount of oxidative stability unlike those with unsaturated acids (Ikhuoria \& Maliki, 2009; Okpala, 2015).

\subsection{Lipids Classes}

Table 3 reported lipid classes, free fatty acids (FFA), Monoacylglycerols (MAG), Diacylglycerols (DAG) and Triacylglycerols (TAG) are found.

Table 3. Lipid classes of mixing safou oil

\begin{tabular}{ll}
\hline \multicolumn{2}{l}{ Lipid classes } \\
\hline Glycerides & Percentage \\
\hline FFA & 5.48 \\
MAG & ND \\
DAG & 5.68 \\
TAG & 88.88 \\
\hline
\end{tabular}

FFA: Free Fatty Acids, MAG: Monoacylglycerol, DAG: Diacylglycerol, TAG: Triacylglycerol, ND: Not Detectable

Regarding the lipid fractions (Table 3), triacylglycerol was the predominant lipid class (88.88\% of the total lipid classes), followed by diacylglycerol (5.68\%), free fatty acids (5.48\%), and monoacylglycerol were present but in very low amount. The presence of free fatty acids may be due to the partial enzymatic hydrolysis of triacylglycerol during the storage of the dried safou pulps.

\subsection{Antioxidant Activity}

The antioxidant activity of the safou pulp oil is presented in table 4. So, inhibition of DPPH was $12.9 \%$. The DPPH radical scavenging activity expressed as IC50 value of the safou oil mixed was $142.25 \mu \mathrm{g} / \mathrm{mL}$ and the ARP value is 7.10-3 (Table 4). IC50 value is inversely proportional to the antioxidant activity. According to the IC50 value, safou pulp oil can be categorized as oil with considerable antioxidant potential. Studies reported that the IC50 value of selected vegetable oil extracts, namely soy, sunflower, rapeseed, corn ranged from 29.7 to 34.0 $\mu \mathrm{g} / \mathrm{mL}$ (Aleksander et al., 2008). The values reported were low to safou pulp oil, but pomegranate seed oil, sesame oil, and blackcurrant seed oil have a high level comparable to safou oil $78 \%, 70 \%$, and $76 \%$, respectively (Badea et al., 2015).

Table 4. Antioxidant activity in mixing safou oil

\begin{tabular}{ll}
\hline Characteristics & Amount \\
\hline DPPH scavenging (\%) & 12.9 \\
IC50 $(\mu \mathrm{g})$ & 142.25 \\
ARP & $7.10^{-3}$ \\
AAI & 0.35 \\
\hline
\end{tabular}

ARP: Antiradical Power, AAI: Antiradical Activity Index

The antiradical activity index (AAI) of safou pulp oil amount is 0.35 . This value shows that this oil has a moderate antioxidant activity because AAI $=0.35<0.5$, according to Scherer and Godoy (2009). These authors established the following criteria of AAI values for plant extracts: poor activity $<0.05<$ moderate $<1.0<$ strong 


\section{$<2.0<$ very strong.}

For an edible oil, it's very important to have an antioxidant activity because it can this oil have a great interest for nutrition. It can absorb free radicals and appear to have a positive impact on cardiovascular and cancer ailments, as attributed to the Mediterranean diet (Agbiolab, 2014).

\section{Conclusion}

The present work envisages that oil obtained from the mixing of several 200 oil samples presents similar characteristics as separated safou oil samples. Acid value shows a greater value; this value can be reduced after refining step. So, many of the physicochemical properties of the mixing oil of safou studied have close similarities with other commercials as groundnut and palm. DPPH radical-scavenging activity obtained was $12.9 \%$. The results of our study suggest that to cope with the weakness of raw materials to enhance this bioresource, mixing oils can be a solution. The antioxidant activity revealed shows that safou oil can be used in a diet for cardiovascular and cancer diseases.

\section{Acknowledgements}

The authors are thankful to Professor David Mampouya, "Université Marien Ngouabi", and Drs. Carine Bertille Tchankou and Ngoua Meye Rick-Léonid "Université des Sciences et Techniques de Masuku" for their skillful assistance for lipid analysis and the complete support throughout the work.

\section{References}

Agbiolab. (2014). Polyphenols and Antioxidant in olive oil. pp. 1.

Ajibesin, K. K. (2011). Dacryodes edulis (G. Don) H.J. Lam: a review on its medicinal, phytochemical, and economical properties. Research Journal Medicinal Plant, 5(1), 32-41. https://doi.org/10.3923/rjmp.2011.32.41

Akubugwo, I. E., Chinyere, G. C., \& Ugbogu, A. E. (2008). Comparative studies on oil from some common plant seeds in Nigeria. Pakistan Journal of Nutrition, 7(4), 570-573. https://doi.org/10.3923/pjn.2008.570.573

Akusu, O. M., \& Wordu, G. O. (2019). Physicochemical and fatty acid profile of Allanblakia and African pear pulp oils. International Journal of Biotechnology and Food Science, 7(2), 14-22. https://doi.org/10.33495/ijbfs_v7i2.19.102

Aleksander, S., Malgorzata, N., \& Elenora, L. (2008). The content and antioxidant activity of phenolic compounds in cold pressed plant oils. Journal of Food Lipids, 15, 137-149. https://doi.org/10.1111/j.1745-4522.2007.00107.x

AFNOR (French Association for Standardization). (2000). Corps gras, graines oléagineuses, produits dérivés : Corps gras et produits dérivés, Tome 1. Paris, France. pp. 350.

Badea, G., Lãcãtusu, I., Badea, N., Ott, C., \& Meghea, A. (2015). Use of various vegetable oils in designing photoprotective nanostructured formulations for UV protection and antioxidant activity. Industrial Crops Products, 67, 18-24. https://doi.org/10.1016/j.indcrop.2014.12.049

Bhatnagar, A. S., Prasanth, K. P. K., Hemavathy, J., \& Gopala, K. A. G. (2009). Fatty acid composition, oxidative stability, and radical scavenging activity of vegetable oil blends with coconut. Journal of American Chemist's Society, 86(10), 991-999. https://doi.org/10.1007/s11746-009-1435-y

Blin, J., Brunschwig, C., Chapuis, A., Changolade, O., Sidibe, S., Noumi, E., \& Girard, P. (2013). Characteristics of vegetable oils for use as fuel in stationary diesel engines - Towards specifications for a standard in West Africa. Renewable and Sustainable Energy. Energy reviews, 22, 580-597. https://doi.org/10.1016/j.rser.2013.02.018

De Carvalho, C. C. C. R., \& Caramujo, M. J. (2018). The various roles of fatty acids. Molecules, 23(10), 2583. https://doi.org/10.3390/molecules23102583

Codex Alimentarius. (2015). Standard for edible fats and oils. Not covered by individual standards. Codex Stan. pp. 19-1981.

Enengedi, I. S., Ekpa, O. D., \& Ikpi, M. E. (2019). Comparative study on the cosmeceutical properties of oil from some Dacryodes edulis (African pear) and Persea americano (Avocado) fruits. American Journal of Chemistry, 9(1), 13-20.

Fomuso, L. B., \& Akoh, C. C. (2002). Lipase-catalyzed acidolysis of olive and caprylic acid in a bench-scale 
packed bed bioreactor. Food Research International, 35(1), 15-21. https://doi.org/10.1016/S0963-9969(00)00158-7

Foukou, E., Achu, M. B., Kansci, G., Ponka, R., Fotso, M., Tchiékang, C., \& Tchouanguep, F. M. (2009). Chemical properties of some cucurbitaceae oils from Cameroon. Pakistan Journal of Nutrition, 8(9), 1325-1334. https://doi.org/10.3923/pjn.2009.1325.1334

Grigoras, C. G. (2012). Valorisation des fruits et sous-produits de l'industrie de transformation des fruits par extraction des composés bioactifs. Thèse, Université d'Orléans, France. pp. 260.

Hatano, T., Kagawa, H., Yasuhara, T., Tasuhara, T., \& Okuda, T. (1988). Two new flavonoids and other constituents in licorice root: Their relative astringency and radical-scavenging effects. Chemical and Pharmaceutical Bulletin, 36, 2090-2097. https://doi.org/10.1248/cpb.36.2090

Helmy, E. H. (1990). Studies on the pigments of some citrus, prune and cucurbit seed oils when processed with or without cottonseed oil. Journal of the American Oils Chemist'Society, 67(6), 376-380. https://doi.org/10.1007/BF02539694

Ikhuoria, E. U., \& Maliki, M. (2007). Characterization of avocado pear (Persea americana) and African pear (Dacryodes edulis) extracts. African Journal of Biotechnology, 6(7), 950-952.

Kadji, B. R. L., Koné, F. M. T., Sika, A. E., \& Dabonne, S. (2016). Physicochemical properties of safou (Dacryodes edulis) fruits grown in Côte d'Ivoire. Journal of Applied Biosciences, 105, 10103-10110. https://doi.org/10.4314/jab.v105i1.7

Kapseu, C., Mapongmetsem, P. M., Silou, T., \& Roques, M. (1998). Physico-chimie du fruit du safoutier (Dacryodes edulis) camerounais. Tropicultura, 16, 38-42.

Karleskind, A., \& Wolf, J. P. (1992). Manuel des corps gras. Tec \& Doc. Paris: Lavoisier.

Loemba-Ndembi, J., \& Silou, T. (2006). Étude des alcools triterpéniques de la fraction insaponifiable de l'huile de la pulpe de safou (Dacryodes edulis). Journal de la Société Ouest-Africaine de Chimie, 21, 29-34.

Mampouya, D. (2006). Contribution à l'optimisation de l'extraction et à la décoloration de d'huile de la pulpe de safou (Dacryodes edulis). Thèse de Doctorat d'état de l'UMNG, Brazzaville. pp. 92.

Mollet, M., Tiki, M. T., Kengue, J., \& Tchoundjeu, Z. (1995). The top ten species in Cameroon, a survey of farmers views on trees. Agroforestry Today, 7(3-4), 14-16.

Nagy, K., \& Tiuca, I-D. (2017). Importance of fatty acids in physiopathology of Human body, Fatty acids, Angel Catala, IntechOpen. https://doi.org/10.5772/67407

Noumi, G. B., Djounja, T., Ngameni, E., \& Kapseu, C. (2014). Influence of the storage time on the fats and oil composition of safou (Dacryodes edulis) dried pulp. International Food Research Journal, 21(5), 1837-1841.

Nzikou, J. M., Bouanga-Kalou, G., Matos, L., Ganongo-Po, F. B., Mboungou-Mboussi, P. S., Moutoula F. E., ... Desobry, S. (2011). Characteristics and nutritional evaluation of seed oil from Roselle (Hibiscus sabdariffa L. ) in Congo-Brazzaville, Curr. Res. J. Biol. Sci., 3, 141-146.

Okpala, B. (2015). Benefits of African pear (Dacryodes edulis). Global Food Book.

Ondo-Azi, A. S., Ella, M. C., Ntsikabaka, S., Silou, T., \& Chalchat, J. C. (2014). Variations in physicochemical characteristics of pulp and oil from safou (Dacryodes edulis): classification and relationships with morphological traits. Journal of Food Agriculture and Environment, 12(2), 212-217.

Rohman, A., \& Che, M. Y. (2009). Monitoring of virgin coconut oil (VCO) adulteration with palm oil using Fourier transform infrared (FTIR) spectroscopy. Journal of Food Lipids, 16, 618-628. https://doi.org/10.1111/j.1745-4522.2009.01170.x

Scherer, R., \& Godoy, H. T. (2009). Antioxidant activity index by the 2,2-diphenul-1-picrulhydrazyl method. Food Chemistry, 112(3), 654-658. https://doi.org/10.1016/j.foodchem.2008.06.026

Silou, T., Rocquelin, G., Mouaragadja, I., \& Gallon, G. (2002). Chemical composition and nutritional characteristics of safou (Dacyodes edulis) of Cameroon and the Congo-Brazzaville, the Congo-Kinshasa and Gabon. Rivista Italiana delle Sostanze Grasse, 79, 177-182.

Silou, T. (2012). Oil and fats for the future. Case study Safou: Dacryodes edulis from Congo basin countries, Nova Edition Publisher NY, USA. pp. 120. 
Stoilova, I., Krastanov, A., Stoyanova, A., Denev, P., \& Gargova, S. (2007). Antioxidant activity of a ginger extract (Zingiber officinale). Food Chemistry, 102, 764-770. https://doi.org/10.1016/j.foodchem.2006.06.023

Suja, K. P., Jayalekshmy, A., \& Arumughan, C. (2005). Antioxidant activity of sesame cake extract. Food Chemistry, 91, 213-219. https://doi.org/10.1016/j.foodchem.2003.09.001

\section{Copyrights}

Copyright for this article is retained by the author(s), with first publication rights granted to the journal.

This is an open-access article distributed under the terms and conditions of the Creative Commons Attribution license (http://creativecommons.org/licenses/by/4.0/). 